\title{
EFEK TIMBAL (Pb) TERHADAP PERTUMBUHAN DAN ADAPTABILITAS Acacia mangium PADA TAILING EMAS
}

\author{
Effect of Lead $(\mathrm{Pb})$ toward the Growth and Adaptability of Acacia mangium on the Gold \\ Tailing
}

\author{
Bayu Winata $^{1 *}$, Basuki Wasis ${ }^{1}$, dan Yadi Setiadi ${ }^{1}$
}

(Diterima Juni 2019/Disetujui Agustsu 2019)

\begin{abstract}
Gold mining is a human activity with high environmental risk through its tailing, due to the heavy metals content. Lead $(\mathrm{Pb})$ is one of dangerous heavy metals in the world, because its toxicity to organism and environment. Phytoremediation is a method to remove hazard pollutant from environment by using plant. Acacia mangium is fast growing and pioneer tree species which mostly grow on the secondary forest as well as marginal land. Usually, this species is used for revegetation on postmining land. Study on Pb effect to A. mangium is an important issue to support phytoremediation advancement as well as for forest restoration. This study aimed to analyze the effect of Pb with several levels toward the growth and adptability of A. mangium on the gold tailing. The results showed that Pb increment on tailing were significantly effect on the growth and adaptability of the plants. A. mangium showed a well performance even on $900 \mathrm{mg}$ Pb/kg tailing with high tolerance index (TI > 100\%). Moreover, this species had ability to accumulate $\mathrm{Pb}$ in the root higher than shoot tissue. A. mangium had a good potency as phitoremediant plant, also as revegetation plant on the marginal land, such as on the gold mining tailing.
\end{abstract}

Key words: Acacia mangium, heavy metal, lead, phytoremediation, $\mathrm{Pb}$

\section{PENDAHULUAN}

Penambangan emas merupakan salah satu aktivitas manusia yang beresiko besar terhadap pencemaran logam berat melalui tailing yang dihasilkan. Tailing adalah residu limbah aktivitas pertambangan yang didominasi oleh tekstur pasir, bersifat marjinal, dan sering kali mengandung unsur logam berat. Ho et al. (2008) menyatakan bahwa $\mathrm{Pb}$ merupakan salah satu logam berat yang ditemukan pada tailing.

$\mathrm{Pb}$ merupakan salah satu unsur logam berat yang tidak esensial bagi metabolisme tanaman, tapi dapat terserap dan terakumulasi pada jaringan tanaman (Aziz 2015), sehingga berbahaya bagi makhluk hidup serta lingkungannya (Nagajyoti et al. 2010 ). Bagi manusia, $\mathrm{Pb}$ bahkan dapat menyebabkan gangguan kesehatan, seperti gangguan organ hati, hemoglobin, enzim, RNA dan DNA, hipertensi, kerusakan otak, bahkan dapat menyebabkan kematian (Herman 2006). Berdasarkan hal tersebut, maka $\mathrm{Pb}$ tercatat sebagai unsur kedua paling berbahaya setelah Arsen (ATSDR 2017).

Fitoremediasi merupakan metode pembersihan polutan dari lingkungan atau ekosistem dengan menggunakan peran tanaman. Tanaman yang cocok untuk fitoremediasi idealnya memiliki beberapa karakteristik, yaitu (1). sifat pertumbuhan yang cepat, (2). produksi biomassa yang tinggi, dan (3). adaptabilitas yang baik terhadap kontaminasi logam berat (Cunningham dan Ow 1996; Rezvani dan

\footnotetext{
${ }^{1}$ Departemen Silvikultur, Fakultas Kehutanan IPB

University

* Penulis koresponden:

E-mail: bayuwinata91@gmail.com bayuwinata@apps.ipb.ac.id
}

Zaefarian 2011). Pohon adalah tanaman/tumbuhan yang potensial untuk diteliti dan dikembangkan sebagai tanaman fitoremedian $\mathrm{Pb}$, karena memiliki potensi biomassa yang besar dan usia yang lebih panjang dibandingkan dengan tumbuhan bawah.

Acacia mangium adalah jenis pohon intoleran dan pionir yang cepat tumbuh. Jenis ini dapat tumbuh pada hutan sekunder atau hutan terganggu yang terbuka. A. mangium dikenal mampu tumbuh pada lahan yang kurang subur termasuk pada lahan-lahan pasca tambang yang marjinal. Berdasarkan hal tersebut, maka pengujian pengaruh $\mathrm{Pb}$ terhadap pertumbuhan serta adaptabilitas A. mangium perlu dilakukan, sehingga dapat diketahui kemampuannya dalam mengakumulasi $\mathrm{Pb}$. Tujuan penelitian ini, yaitu menganalisis efek $\mathrm{Pb}$ pada beberapa konsentrasi terhadap pertumbuhan dan adaptabilitas semai $A$. mangium dalam mengakumulasi $\mathrm{Pb}$ pada media tailing emas.

\section{METODE PENELITIAN}

\section{Waktu dan Tempat Penelitian}

Penelitian dilaksanakan selama tiga bulan di Rumah Kaca Ekologi Hutan, Fakultas Kehutanan IPB. Analisis tanah dan jaringan dilaksanakan di Laboratorium Ilmu Tanah dan Sumberdaya Lahan Fakultas Pertanian IPB. Adapun lokasi pengambilan tailing dilakukan di Pongkor, Bogor, Jawa Barat.

\section{Alat dan Bahan}

Alat yang digunakan, yaitu sekop, mangkuk, timbangan (neraca analitik dan timbangan digital), 
mistar, kaliper digital, gelas ukur, oven, tallysheet, alat tulis, kamera, software Ms. Excel dan SAS 9.1.3 portable. Bahan yang digunakan, yaitu semai $A$. mangium, tailing emas, $\mathrm{Pb}\left(\mathrm{NO}_{3}\right)_{2}$, polybag $(20 \times 20$ $\mathrm{cm})$, air minum mineral, dan pupuk cair.

\section{Prosedur}

Penelitian ini dilakukan menggunakan rancangan acak lengkap (RAL). Perlakuan yang diberikan yaitu pemberian $\mathrm{Pb}\left(\mathrm{NO}_{3}\right)_{2}$ yang terdiri dari lima taraf $(\mathrm{P} 0=0$ $\mathrm{mg} \mathrm{Pb} / \mathrm{kg}$ tailing, $\mathrm{P} 1=150 \mathrm{mg} \mathrm{Pb} / \mathrm{kg}$ tailing, $\mathrm{P} 2=300$ $\mathrm{mg} \mathrm{Pb} / \mathrm{kg}$ tailing, $\mathrm{P} 3=450 \mathrm{mg} \mathrm{Pb} / \mathrm{kg}$ tailing (Setyaningsih et al. 2012), dan $\mathrm{P} 4=900 \mathrm{mg} \mathrm{Pb} / \mathrm{kg}$ tailing). Setiap perlakuan diulang sebanyak tiga kali. Adapun prosedur penelitian dijelaskan sebagai berikut:

\section{Persiapan Media dan Tanaman}

Media berupa tailing emas ditimbang seberat $1 \mathrm{~kg}$, lalu dimasukan ke dalam polybag. Semai A. mangium berumur tiga bulan masing-masing dipersiapkan dengan tinggi dan diameter yang relatif sama, sehat, serta bebas dari hama dan penyakit. Semai kemudian ditanam pada media yang telah dipersiapkan. Kemudian, dilakukan pemberian larutan $\mathrm{Pb}\left(\mathrm{NO}_{3}\right)_{2}$ masing-masing sebanyak $50 \mathrm{ml}$ sesuai dengan taraf yang ditentukan, yaitu 0, 150, $300,450 \mathrm{mg} \mathrm{Pb} / \mathrm{kg}$ tailing (Setyaningsih et al. 2012) dan $900 \mathrm{mg} \mathrm{Pb} / \mathrm{kg}$ tailing. Setiap polybag tersebut, lalu diletakkan di atas wadah/mangkung.

\section{Pemeliharaan}

Pemeliharaan yang dilakukan berupa pemupukan dan pemberian air bagi tanaman. Pupuk yang digunakan yaitu pupuk cair yang mengandung unsur hara makro dan unsur hara mikro. Pupuk cair sebnayak 1 liter diencerkan terlebih dahulu dengan 60 liter air mineral, kemudian diberikan pada setiap tanaman sesuai kapasitas lapangnya. Pemupukan dilakukan sekali pada saat semai telah ditanam. Pemberian air bagi tanaman dilakukan dengan cara menambahkan air ke dalam mangkuk penyangga polybag untuk menghindari pencucian $\mathrm{Pb}$ yang telah diberikan. Adapun air yang digunakan merupakan air mineral untuk dikonsumsi oleh manusia dengan asumsi bahwa air tersebut tidak memiliki kandungan $\mathrm{Pb}$.

\section{Analisis Tailing dan Jaringan Tanaman}

Analisis karakteristik tailing dilakukan sebelum dan sesudah penelitian untuk mengetahui kandungan hara dan Pb-nya. Analisis jaringan tanaman dilakukan setelah penelitian untuk mengetahui akumulasi $\mathrm{Pb}$ pada jaringan tanaman (bagian pucuk dan bagian akar). Analisis tailing dan jaringan tanaman dilakukan di Laboratorium Ilmu Tanah dan Sumberdaya Lahan Fakultas Pertanian IPB.

\section{Observasi dan Pengambilan Data}

Observasi dan pengambilan data dilakukan terhadap variabel tinggi, diameter, dan panjang akar. Selain itu, dilakukan pengambilan data terhadap parameter berikut ini:

\section{a. Berat kering total (BKT)}

Semai A. mangium dipanen setelah 12 minggu, lalu dipisahkan antara pucuk (daun dan batang) dengan bagian akar. Kemudian, bagian tanaman tersbeut dioven pada suhu $800 \mathrm{C}$ selama 24 jam, lalu ditimbang.

\section{b. Nisbah pucuk akar (NPA)}

NPA diperoleh dengan membandingkan nilai BKT pucuk dengan BKT akar.

\section{c. Bioakumulasi timbal (Pb)}

Biokamulasi $\mathrm{Pb}$ yang diikat oleh tanaman dihitung menggunakan rumus berikut (Hardiani 2009):

Bioakumulasi $=\frac{\text { berat } \mathrm{Pb} \text { pada (akar atau daun })}{\text { berat kering tanaman (akar atau daun })}(\mathrm{mg} / \mathrm{kg})$

\section{Berat $\mathrm{Pb}=$ konsentrasi $\mathrm{Pb}$ x berat kering}

Keterangan: Konsentrasi $\mathrm{Pb}$ (pada akar atau daun) Berat kering (akar atau daun)

\section{d. Faktor biokonsentrasi (FB) dan faktor trasnlokasi (FT) (Magaña et al. 2011):}

$$
\begin{aligned}
& \mathrm{FB}=\frac{\text { konsentrasi } \mathrm{Pb} \text { pada jaringan (akar atau daun) }}{\text { konsentrasi } \mathrm{Pb} \text { pada tanah (media) }} \\
& \mathrm{FT}=\frac{\text { konsentrasi } \mathrm{Pb} \text { pada jaringan pucuk }}{\text { konsentrasi } \mathrm{Pb} \text { pada jaringan akar }}
\end{aligned}
$$

\begin{tabular}{|c|c|c|c|c|c|c|c|c|c|c|}
\hline \multirow{2}{*}{$\begin{array}{l}\text { Perlakuan } \\
\text { P0 (0 mg Pb/kg tailing) }\end{array}$} & \multicolumn{2}{|c|}{$\Delta$ Tinggi $(\mathrm{cm})$} & \multicolumn{2}{|c|}{$\Delta$ Diameter $(\mathrm{mm})$} & \multicolumn{2}{|l|}{$\operatorname{BKT}(g)$} & \multicolumn{2}{|c|}{ Panjang akar (cm) } & \multicolumn{2}{|c|}{ NPA } \\
\hline & 15.3 & $\mathrm{a}$ & 0.84 & $\mathrm{a}$ & 9.28 & $\mathrm{ab}$ & 21.1 & $\mathrm{a}$ & 3.2 & $\mathrm{a}$ \\
\hline P1 (150 mg Pb/kg tailing) & 14.2 & $a b$ & 0.85 & $\mathrm{a}$ & 8.42 & $\mathrm{bc}$ & 21.9 & $\mathrm{a}$ & 3 & $\mathrm{a}$ \\
\hline P2 (300 mg Pb/kg tailing) & 14.0 & $\mathrm{ab}$ & 0.88 & $\mathrm{a}$ & 7.90 & $\mathrm{c}$ & 23.3 & $\mathrm{a}$ & 3 & $\mathrm{a}$ \\
\hline P3 (450 mg Pb/kg tailing) & 12.2 & $\mathrm{~b}$ & 0.78 & $\mathrm{a}$ & 9.58 & $\mathrm{ab}$ & 22.6 & $\mathrm{a}$ & 3.3 & $\mathrm{a}$ \\
\hline P4 (900 mg Pb/kg tailing) & 12.2 & $\mathrm{~b}$ & 0.72 & $\mathrm{a}$ & 9.93 & $\mathrm{a}$ & 23.3 & $\mathrm{a}$ & 4 & $\mathrm{a}$ \\
\hline Nilai signifikan & 0.042 & $*$ & 0.111 & tn & 0.028 & $*$ & 0.077 & tn & 0.566 & \\
\hline
\end{tabular}

Tabel 1 Pengaruh $\mathrm{Pb}$ terhadap pertumbuhan semai A.mangium pada tailing emas

Angka yang diikuti oleh huruf yang sama dalam satu kolom dan satu kelompok perlakuan menunjukkan perlakuan tidak berbeda nyata pada selang kepercayaan 95\%; * = perlakuan berpengaruh nyata pada selang kepercayaan 95\% dengan nilai signifikan (p $<0.05)$; th = perlakuan tidak berpengaruh nyata pada selang kepercayaan $95 \%$ dengan nilai signifikan ( $\mathrm{p}>0.05)$. 


\section{e. Indeks Toleransi Timbal (Pb) (Rabie 2005):}

$$
\mathrm{IT}=\frac{\text { berat kering akar tanaman dengan perlakuan } \mathrm{Pb}}{\text { berat kering akar tanpa perlakuan } \mathrm{Pb}} \times 100 \%
$$

\section{HASIL DAN PEMBAHASAN}

\section{Efek Pb terhadap pertumbuhan Semai $A$. mangium} pada Tailing Emas

Pertumbuhan tanaman dipengaruhi oleh faktor internal (genetik) dan eksternal (lingkungan). Salah satu faktor eksternal yang dapat mempengaruhi pertumbuhan semai A. mangium pada tailing, kandungan logam berat yang merupakan unsur tidak ensensial dan berpotensi sebagai toxic substance. Pertumbuhan tanaman adalah hal yang penting diamati untuk mengetahui pengaruh lingkungan tempat tumbuhnya. Cunningham dan DW (1996) menyatakan bahwa dalam konsep fitoremediasi pertumbuhan tanaman memiliki hubungan dengan kemampuannya dalam menyerap logam berat. Tabel 1 menyajikan pengaruh $\mathrm{Pb}$ terhadap pertumbuhan semai A. mangium pada tailing emas selama tiga bulan.

Peningkatan konsentrasi $\mathrm{Pb}$ memberikan pengaruh nyata terhadap pertumbuhan tinggi dan biomassa (BKT) A. mangium selama tiga bulan observasi. Konsentrasi 0 $\mathrm{mg} \mathrm{Pb} / \mathrm{kg}$ tailing menghasilkan pertumbuhan tinggi $A$. mangium sebesar $15.3 \mathrm{~cm}$, lalu mengalami penurunan yang signifikan seiring dengan kenaikan konsentrasi $\mathrm{Pb}$ yang diterapkan. Pertumbuhan tinggi terendah semai $A$. mangium terjadi pada konsentrasi 450 dan $900 \mathrm{mg}$ $\mathrm{Pb} / \mathrm{kg}$ tailing, yaitu hanya mencapai $12.2 \mathrm{~cm}$. Keberadaan $\mathrm{Pb}$ dengan beberapa konsentrasi, tidak
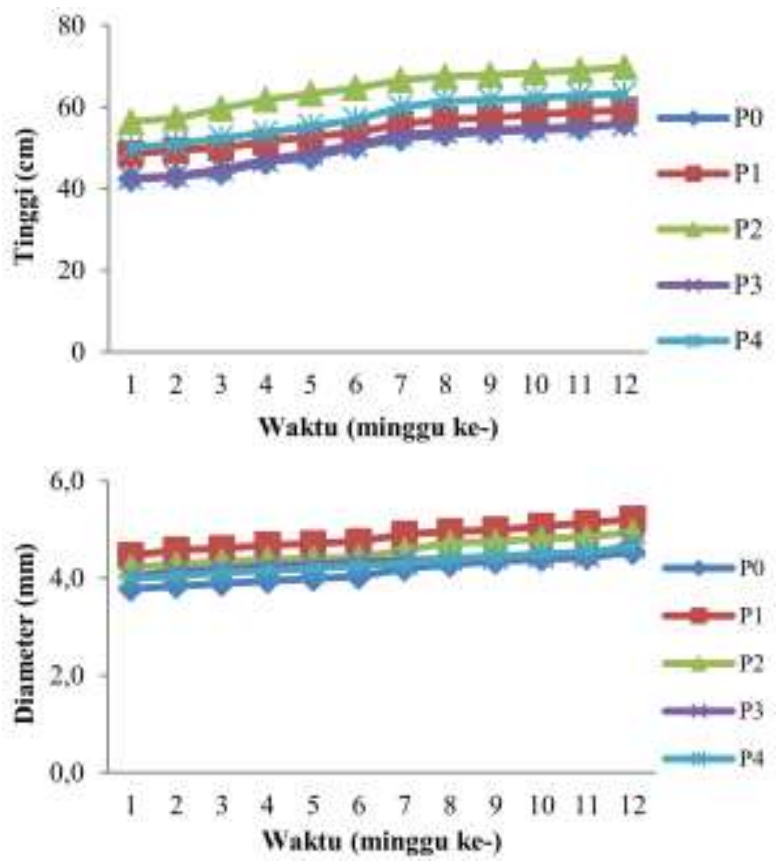

Gambar 1 Laju pertumbuhan tinggi dan diameter semai A. mangium pada berbagai konsentrasi $\mathrm{Pb}$ selama 12 minggu. $\mathrm{P} 0=0$ $\mathrm{mg} \mathrm{Pb} / \mathrm{kg}$ tailing, $\mathrm{P} 1=150 \mathrm{mg} \mathrm{Pb} / \mathrm{kg}$ tailing, $\mathrm{P} 2=300 \mathrm{mg} \mathrm{Pb} / \mathrm{kg}$ tailing, $\mathrm{P} 3=450 \mathrm{mg} \mathrm{Pb} / \mathrm{kg}$ tailing, dan $\mathrm{P} 4=900$ $\mathrm{mg} \mathrm{Pb} / \mathrm{kg}$ tailing memberikan pengaruh signifikan terhadap diameter $A$. mangium. Pertumbuhan dimeter merupakan pertumbuhan sekunder pada jaringan kambium tanaman (Darmawan dan Baharsjah 2010). Pada fase semai, A. mangium diduga belum mengalami pertumbuhan sekunder, sebab sedang mengalami fase pertumbuhan primer, seperti pertumbuhan tinggi (vertikal). Namun demikian, rata-rata pertumbuhan diameter semai $A$. mangium pada mengalami penurunan pada konsentrasi 450 dan $900 \mathrm{mg} \mathrm{Pb} / \mathrm{kg}$ tailing.

Secara umum, rata-rata pertumbuhan tinggi dan diameter menunjukkan penurunan seiring dengan peningkatan konsentrasi $\mathrm{Pb}$ pada tailing, tetapi laju pertumbuhan tinggi dan diameter semai A. mangium menunjukkan peningkatan terhadap waktu selama 12 minggu (Gambar 1). Kondisi tersebut mengindikasikan jika $A$. mangium masih adaptif dan mampu tumbuh pada media yang terkontaminasi $\mathrm{Pb}$ pada berbagai konsentrasi yang diberikan, bahkan pada penambahan $\mathrm{Pb}$ hingga konsentrasi $900 \mathrm{mg} \mathrm{Pb/kg} \mathrm{tailing.}$

Dari aspek pembentukan biomassa, penambahan $\mathrm{Pb}$ pada konsentrasi 450 - $900 \mathrm{mg} \mathrm{Pb} / \mathrm{kg}$ tailing justru menghasilkan biomassa (BKT) tertinggi, yaitu berturutturut 9.58 dan $9.93 \mathrm{~g}$ yang tidak berpengaruh nyata dengan konsentrasi $0 \mathrm{mg} \mathrm{Pb} / \mathrm{kg}$ tailing. Hal ini mengindikasikan jika pertumbuhan biomassa semai $A$. mangium relatif tidak terganggu dengan keberadaan $\mathrm{Pb}$.

Selain pertumbuhan diameter, konsentrasi $\mathrm{Pb}$ juga tidak berpengaruh signifikan terhadap panjang akar semai A. magium (Tabel 1). Akar A. mangium cenderung menunjukkan pertumbuhan terpanjang pada penambahan $900 \mathrm{mg} \mathrm{Pb} / \mathrm{kg}$ tailing. Fenomena pada akar tersebut diduga sebagai adaptasi akar menghindari keberadaan $\mathrm{Pb}$ pada konsentrasi tinggi, sehingga akar dapat memperluas jerapan air dan hara yang dapat digunakan untuk mendukung berbagai metabolisme. Liu et al. (2000) menyatakan bahwa meskipun secara umum $\mathrm{Pb}$ tidak dipertimbangkan sebagai elemen esensial bagi pertumbuhan tanaman, tapi dalam jumlah tertentu $\mathrm{Pb}$ mungkin berperan dalam menstimulasi pertumbuhan beberapa jenis tanaman. Ketika akar menyerap air dan hara, ion-ion dan molekul termasuk $\mathrm{Pb}$ di sekitar perakaran bergerak ke dalam akar melalui aliran massa dan proses difusi (Fahr et al. 2013).

NPA merupakan perbandingan biomassa kering bagian pucuk dan akar tanaman. Wasis et al. (2015) menyatakan bahwa NPA dapat menggambarkan kemampuan akar menjalankan fungsinya secara optimal dalam media tumbuh. Keberadaan $\mathrm{Pb}$ pada beberapa konsentrasi tidak berpengaruh signifikan terhadap NPA semai A. mangium. Secara keseluruhan rata-rata nilai NPA $\geq 1$. Herliyana et al. (2012) menyatakan bahwa pertumbuhan tanaman yang baik dapat ditunjukkan oleh nilai NPA yang berkisar antara $1-3$. NPA dipengaruhi oleh beberapa faktor, diantaranya: sifat genetik tanaman, ketersediaan unsur hara, dan persaingan cahaya (Mokany et al. 2006; Wulandari dan Susanti 2012). Pertumbuhan semai A. mangium yang baik berdasarkan NPA, diduga dipengaruhi oleh keberadaan nitrat yang berasal dari $\mathrm{Pb}\left(\mathrm{NO}_{3}\right)_{2}$ (Ho et al. 2008). Indranada (1989) menyatakan bahwa unsur nitrogen diserap oleh tanaman dalam bentuk nitrat $\left(\mathrm{NO}_{3}^{-}\right)$. Nitrogen merupakan unsur hara yang penting bagi
Perlak

P0 (0 n P1 (15

$\mathrm{P} 2(30$

$\mathrm{P} 3(45$

P4 (90 
pertumbuhan vegetatif dan pembentukan protein pada tanaman (Hardjowigeno 2003).

Studi lain menemukan bahwa semai pohon dapat tumbuh pada media yang terkontaminasi $\mathrm{Pb}$, diantarnya Antocephalus candamba dan Paraserianthes falcataria masih dapat tumbuh pada media dengan kontaminasi $450 \mathrm{mg} \mathrm{Pb} / \mathrm{kg}$ (Setyaningsih 2012). Selain itu, pada studi yang dilakukan Magaña et al. (2011) menemukan bahwa Acacia farnesiana masih dapat tumbuh dengan baik dalam media yang terkontaminasi 250 dan $500 \mathrm{mg}$ $\mathrm{Pb} / \mathrm{L}$. Secara umum, peningkatan kontaminasi $\mathrm{Pb}$ pada tempat tumbuh, akan berdampak terhadap penurunan pertumbuhan tanaman (Niu et al. 2007; Ho et al. 2008).

\section{Efek Pb terhadap Adaptabilitas Semai A. mangium pada Tailing Emas}

Adaptabilitas tanaman dalam merespon keberadaan logam berat di tempat tumbuhnya dapat digambarkan oleh bioakumulasi logam berat dan indeks toleransi. Bioakumulasi merupakan kemampuan tanaman untuk mengakumulasi logam berat pada jaringannya.

Akumulasi $\mathrm{Pb}$ tertinggi oleh semai $A$. mangium (Tabel 2) dihasilkan pada semai dengan perlakuan P4 yang mencapai total akumulasi sebesar $460.78 \mathrm{mg} / \mathrm{kg}$. Berdasarkan lokasi jaringannya, A. mangium mengakumulasi $\mathrm{Pb}$ pada jaringan perakaran (446.48 $\mathrm{mg} / \mathrm{kg}$ ) jauh lebih besar daripada akumulasi $\mathrm{Pb}$ pada

\section{Tabel 2 Pengaruh konsentrasi $\mathrm{Pb}$ terhadap bioakumulasi semai A. mangium}

\begin{tabular}{lccc}
\hline \multirow{2}{*}{ Perlakuan } & \multicolumn{3}{c}{ Akumulasi (mg/kg) } \\
\cline { 2 - 4 } & Pucuk & Akar & Total \\
\hline $\begin{array}{l}\text { P0 (0 mg Pb/kg } \\
\text { tailing) } \\
\text { P1 (150 mg Pb/kg } \\
\text { tailing) }\end{array}$ & 5.88 & 17.66 & 23.54 \\
$\begin{array}{l}\text { P2 (300 mg Pb/kg } \\
\text { tailing) }\end{array}$ & 8.42 & 120.24 & 128.66 \\
$\begin{array}{l}\text { P3 (450 mg Pb/kg } \\
\text { tailing) }\end{array}$ & 3.36 & 123.6 & 126.96 \\
$\begin{array}{l}\text { P4 (900 mg Pb/kg } \\
\text { tailing) }\end{array}$ & 21.02 & 200.96 & 221.98 \\
\hline
\end{tabular}

Tabel 3 Faktor biokonsentrasi dan faktor translokasi semai A. mangium

\begin{tabular}{llll}
\hline \multirow{2}{*}{ Perlakuan } & \multicolumn{2}{c}{ FB } & \\
\cline { 2 - 3 } & Pucuk & Akar & FT \\
\hline $\begin{array}{l}\mathrm{P} 0(0 \mathrm{mg} \mathrm{Pb} / \mathrm{kg} \\
\text { tailing) }\end{array}$ & 0.9 & 2.8 & 0.33 \\
$\begin{array}{l}\mathrm{P} 1(150 \mathrm{mg} \mathrm{Pb} / \mathrm{kg} \\
\text { tailing) }\end{array}$ & 0.3 & 3.8 & 0.07 \\
$\begin{array}{l}\mathrm{P} 2(300 \mathrm{mg} \mathrm{Pb} / \mathrm{kg} \\
\text { tailing) }\end{array}$ & 0.1 & 2.1 & 0.03 \\
$\begin{array}{l}\mathrm{P} 3(450 \mathrm{mg} \mathrm{Pb} / \mathrm{kg} \\
\text { tailing) }\end{array}$ & 0.2 & 1.8 & 0.10 \\
$\begin{array}{l}\mathrm{P} 4(900 \mathrm{mg} \mathrm{Pb} / \mathrm{kg} \\
\text { tailing) }\end{array}$ & 0.1 & 1.6 & 0.03
\end{tabular}

jaringan pucuk (14.39 mg/kg). Sharma dan Dubey (2005) menyatakan bahwa kandungan $\mathrm{Pb}$ bervariasi pada jaringan tanaman dan cenderung menurun dari akar menuju pucuk. Selain itu, semakin besar konsentrasi $\mathrm{Pb}$ pada media tailing, maka bioakumualasinya juga semakin besar. Hal tersebut sesuai dengan prinsip penyerapan logam $\mathrm{Pb}$ oleh tanaman, yaitu semakin besar kandungan $\mathrm{Pb}$ dalam media, maka semakin besar juga serapan $\mathrm{Pb}$ oleh tanaman (Magaña et al. 2011; Haryanti 2013; Malar et al. 2014).

Tabel 3 menyajikan faktor biokonsentrasi (FB) dan faktor translokasi (FT) tanaman pada berbagai perlakuan penambahan $\mathrm{Pb}$. FB menunjukkan nisbah $\mathrm{Pb}$ yang terdapat pada jaringan tanaman dengan $\mathrm{Pb}$ pada media, sedangkan FT menunjukkan nisbah $\mathrm{Pb}$ pada jaringan pucuk dengan $\mathrm{Pb}$ pada jaringan akar.

Pada semai A. mangium, nilai FB pada akar relatif lebih besar daripada pucuk. Nilai FB berkisar dari $1.6-3.8$ untuk akar dan $0.1-0.9$ untuk pucuk. Nilai FB berbanding lurus dengan nilai biokamulasi $\mathrm{Pb}$ yang dilakukan oleh tanaman. Hal tersebut mengindikasikan bahwa $\mathrm{Pb}$ yang diakumlasi oleh jaringan tanaman lebih banyak disimpan pada jaringan akar dibandingkan yang disimpan di jaringan pucuk.Liu et al. (2008) berpendapat bahwa konsentrasi $\mathrm{Pb}$ di pucuk relatif lebih rendah bila dibandingkan dengan $\mathrm{Pb}$ di bagian perakaran, serta akan meningkat seiring dengan peningkatan konsentrasi $\mathrm{Pb}$ pada media tumbuh. Sementara itu, nilai FT semai $A$. mangium berkisar pada $0.03-0.33$. Zou et al. (2012) menyatakan bahwa nilai FT $<1.0$ menunjukkan jika konsentrasi logam berat di pucuk lebih rendah daripada di akar.

Hardiani (2009) berpendapat bahwa pada dasarnya, mekanisme penyerapan dan akumulasi logam berat oleh tanaman meliputi: 1) penyerapan logam oleh akar, khususnya di area rhizosfer, 2) translokasi logam dari akar ke bagian tanaman lainnya mengikuti aliran transpirasi melalui jaringan pengangkut (xilem dan floem), dan 3) lokalisasi logam pada sel dan jaringan.

Indeks Toleransi (IT) dapat menunjukkan kemampuan tanaman yang adaptif pada suatu tempat tumbuh. Perlakuan penambahan $\mathrm{Pb}$ pada media memberikan pengaruh yang bervariasi terhadap nilai IT (Gambar 2). Nilai IT semai A. mangium diketahui berkisar antara $100-172 \%$. Penambahan $\mathrm{Pb}$ dengan konsentrasi $450 \mathrm{mg} \mathrm{Pb} / \mathrm{kg}$ tailing menghasilkan IT

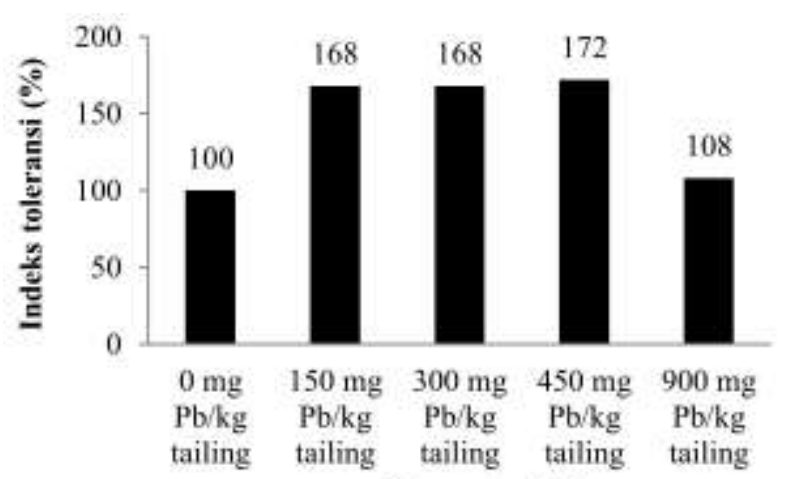

Konsentrasi $\mathbf{P b}$

Gambar 2 Indeks toleransi semai A. mangium 
tertinggi, dan menurun pada penambahan $\mathrm{Pb}$ hingga konsentrasi $900 \mathrm{mg} \mathrm{Pb} / \mathrm{kg}$ tailing, dimana IT mencapai $108 \%$. Secara umum, IT cenderung meningkat hingga penambahan $\mathrm{Pb}$ pada konsentrasi $450 \mathrm{mg} \mathrm{Pb} / \mathrm{kg}$ tailing dan menurun pada konsentrasi $900 \mathrm{mg} \mathrm{Pb} / \mathrm{kg}$ tailing. IT spesies ini terhadap kontaminasi $\mathrm{Pb}$ masih berada pada level di atas $100 \%$. Hal tersebut mengindikasikan jika semai A. mangium memiliki toleransi terbaik, bahkan pada konsentrasi $900 \mathrm{mg} \mathrm{Pb} / \mathrm{kg}$ tailing. Magaña et al. (2011) menemukan bahwa $A$. farnesiana memiliki IT yang sangat tinggi, yaitu $>100 \%$ pada pemaparan $\mathrm{Pb}$ sebesar $250-500 \mathrm{mg} / \mathrm{l}$, lalu mengalami penurunan menjadi < 75\% ketika paparan $\mathrm{Pb}$ berada pada konsentrasi $750 \mathrm{mg} / \mathrm{l}$. Arisusanti dan Purwani (2013) menyatakan bahwa pada saat menyerap logam berat, tanaman yang adaptif akan membentuk suatu enzim reduktase pada akar. Enzim reduktase tersebut berfungsi untuk mereduksi logam yang kemudian logam diangkut di dalam membran akar.

\section{SIMPULAN}

Keberadaan $\mathrm{Pb}$ pada beberapa konsentrasi di dalam media tailing emas memberikan pengaruh terhadap pertumbuhan dan adaptabilitas semai $A$. mangium. Semai A. mangium memiliki pertumbuhan dan adaptabilitas yang baik terhadap media yang terkontaminasi $\mathrm{Pb}$ hingga penambahan $900 \mathrm{mg} \mathrm{Pb} / \mathrm{kg}$ tailing, dimana indeks toleransinya mencapai nilai > $100 \%$. Semai A. mangium memiliki kemampuan dalam mengakumulasi $\mathrm{Pb}$ hingga $460.78 \mathrm{mg} / \mathrm{kg}$ tailing. Adapun zona perakaran semai A. mangium merupakan bagian yang mengakumulasi $\mathrm{Pb}$ lebih tinggi daripada bagian pucuk. Berdasarkan hal tersebut, maka $A$. mangium memiliki potensi yang baik untuk digunakan sebagai tanaman revegetasi pada lahan pasca tambang sekaligus tanaman fitoremedian logam Timbal.

\section{DAFTAR PUSTAKA}

[ATSDR] Agency for Toxic Substances and Disease Registry. 2017. Priority list of hazardous substances [Internet]. [diunduh 2019 Juli 15]. Tersedia pada: https://www.atsdr.cdc.gov/spl/.

Aziz T. 2015. A mini review on Lead $(\mathrm{Pb})$ toxicity in plans. Journal of Biology and Life Science. 6(2): 91-101.

Cunningham SD, Ow DW. 1996. Promises and prospect of phytoremediation. Plant Physiol. 110: 715-719.

Fahr M, Laplaze L, Bendaou N, Hocher V, El Mzibri M, Bogusz D, Smouni A. 2013. Effect of lead on root growth. Frontiers in Plant Sience. 4(175): 17. doi: $10.3389 /$ fpls.2013.00175.

Hardiani H. 2009. Potensi tanaman dalam mengakumulasi logam $\mathrm{Cu}$ pada media tanah terkontaminasi limbah padat industri kertas. $B S$ 44(1): 27-40.

Hardjowigeno S. 2003. Ilmu Tanah. Jakarta (ID): Akademika Pressindo.

Haryanti D, Budianta D, Salni. 2013. Potensi beberapa jenis tanaman hias sebagai fitoremediasi logam timbal $(\mathrm{Pb})$ dalam tanah. Jurnal Penelitian Sains. 16(2D): 52-58.

Herliyana EN, Achmad, Putra A. 2012. Pengaruh pupuk organik cair terhadap pertumbuhan bibit jabon (Anthocephalus cadamba miq.) dan ketahanannya terhadap penyakit. Jurnal Silvikultur Tropika. 03(03): 168-173.

Herman DZ. 2006. Tinjauan terhadap tailing mengandung unsur pencemar Arsen (As), Merkuri $(\mathrm{Hg})$, Timbal $(\mathrm{Pb})$, dan Kadmium $(\mathrm{Cd})$ dari sisa pengolahan bijih logam. Jurnal Geologi Indonesia. 1(1): 31-36.

Indranada HK. 1989. Pengelolaan Kesuburan Tanah. Semarang (ID): Bina Aksara.

Liu D, Jiang W, Liu C, Xin C, Hou W. 2000. Uptake and accumulation of lead by roots, hypocotyls and shoots of Indian mustard (Brassica juncea (L.). Bioresource Technology. 71(2000): 273-277.

Liu J-n. Zhou Q, Sun T, Ma LQ, Wang S. 2008. Growth responses of three ornamental plants to $\mathrm{Cd}$ and $\mathrm{Cd}-$ $\mathrm{Pb}$ stress and their metal acumulation characteristics. Journal of Hazardous Materials. 151(2008): 261-267.

Magaña AM, Torres EF, Cabrera FR, Sepulveda TLV. 2011. Lead bioaccumulation in Acacia farnesiana and its effect on lipid peroxidation and glutathione production. Plant Soil 2011(339): 377-389. doi: 10.1007/s11104-010-0589-6.

Malar S, Vikram SS, Favas PJC, Perumal V. 2014. Lead heavy metal toxicity induced changes on growth and antioxidative enxymes level in water hyacinths (Eichhornia crassipes (Mart.). Botanical Studies. 55(54): 2-11.

Mokany K, Raison RJ, Prokushkin NS. 2006. Critical analysis of root:shoot rations in terrestrial biomes. Global Change Biology. 12: 84-96.

Kopittke PM, Asher CJ, Kopittke RA, Menzies NW. 2007. Toxic effect of $\mathrm{Pb} 2+$ on growth of cowpea (Vigna unguiculata). Environmental Pollution. 150(2007) 280-287.

Nagajyoti PC, Lee KD, Sreekanth TVM. 2010. Heavymetals, occurrence, and toxicity for plants: a review. Environ Chem Lett. 8(3): 199-216.

Niu ZX, Sun LN, Sun TH, Li YS, Wang H. 2007. Evaluation of phytoextracting cadmium and lead by sunflower, ricinus, alfalfa and mustard in hydroponic culture. J Environ Sci. 19(8): 961-967.

Rabie GH. 2005. Contribution of arbuscular mycorrhizal fungus to red kidney and wheat plants tolerance grown in heavy metal-polluted soil. African Journal of Biotechnology. 4(4): 332-345.

Rezvani M, Zaefarian F. 2011. Bioaccumulation and translocation factors of cadmium and lead in Aelurops littoralis. Australian Journal of Agricultural Engineering. 2(4): 114-119.

Setyaningsih L. 2012. Adaptabilitas semai tanaman hutan terhadap timbal pada media tailing dengan aplikasi kompos aktif dan fungi mikoriza arbuskula [disertasi]. Bogor (ID): Sekolah Pascasarjana Institut Pertanian Bogor.

Setyaningsih L, Setiadi Y, Sopandie D, Budi SW. 2012. Organic acid characteristic and Tolerance of sengon (Paraserianthes falcataria L Nielsen) to 
lead. JMHT. 18(3): 177-183. doi: 10.7226/jtfm.18.2.177.

Sharma P, Dubey RS. 2005. Lead toxicity in plants. Braz. J. Plant Physiol. 17(1): 35-52.

Wasis B, Sandrasari A. 2011. Pengaruh penambahan pupuk kompos terhadap pertumbuhan semai mahoni (Swietenia macrophylla King.) pada media tanah bekas tambang emas (tailing). Jurnal Silvikultur Tropika. 3(1): 109-112.

Wasis B, Mulyana D, Winata B. 2015. Pertumbuhan semai jabon (Anthocephalus cadamba) pada media bekas tambang pasir dengan penambahan sub soil dan arang tempurung kelapa. Jurnal Silvikultur Tropika. 6(2): 93-100.

Wulandari AS, Susanti S. Aplikasi pupuk daun organik untuk meningkatkan pertumbuhan bibit jabon (Anthocephalus cadamba Miq.). Jurnal Silvikultur Torpika 03(02): 137-142.

Zou T, Li T, Zhang X, Yu H, Huang H. 2012. Lead accumulation and phytostabilization potential of dominant plant species growing in a lead-zinc mine tailing. Environ Earth Sci. 65(2012): 621630. doi: 10.1007/s12665-011-1109-6. 